\title{
Hubungan Dukungan Sosial dan Pemberitaan Media dengan Kecemasan Ibu Menjalani Kehamilan Masa Pandemi COVID-19 di Kota Medan Tahun 2020
}

\author{
Masta Melati Hutahaean ${ }^{1, *}$, Afnizar Wahyu ${ }^{2}$ \\ ${ }^{1}$ STIKes Murni Teguh, Jl. Batu Sihombing, Desa Medan Estate, Kecamatan Percut Sei Tuan, Kab. Deli Serdang, 20111, Indonesia \\ ${ }^{1}$ mastahutahaean0201012@gmail.com*; ${ }^{2}$ wafniwahyu@gmail.com \\ *corresponding author
}

ARTICLE INFO

Article history

24-08-2021

$15-09-2021$

$02-10-2021$

Keywords

Social support

Media announcement

Pregnant women anxiety

\section{ABSTRACT}

Maternal Mortality Rate (MMR) is one indicator to see the success of maternal health efforts. Since WHO officially declared the corona virus outbreak (COVID-19) as a pandemic. The COVID-19 pandemic has hit almost all countries in the world and has an impact on various health and non-health sectors. It is undeniable that this condition will cause maternal anxiety during pregnancy. The sampling technique in this study was carried out by the quota sampling technique. Analyzed by chi-square test. The results of the study on the relationship between social support and maternal anxiety during pregnancy showed that there was a relationship between social support and maternal anxiety during pregnancy ( $\mathrm{p}$ value 0.003 ) with an OR of 3.187 which means that pregnant women with good social support have an estimated chance of 3.187 times experiencing mild anxiety levels. compared to pregnant women with less social support. In addition, the results of the study show that there is a relationship between media coverage and maternal anxiety during pregnancy ( $\mathrm{p}$ value $<0.001$ ) with an OR of 4.56 which means that pregnant women who are exposed to positive media coverage have an estimated 4.56 times chance of experiencing mild anxiety levels compared to those who are exposed to positive media coverage. pregnant women with negative media coverage. It can be concluded that social support and media coverage have been shown to be associated with maternal anxiety during pregnancy during the COVID-19 pandemic. It is recommended for health workers to be able to adapt to health services that are adapted to health protocols that focus on efforts to promote health, prevent disease and empower pregnant women. Although visits to health facilities are only prioritized for pregnant women who have problems, health workers are still required to be able to innovate in developing education for pregnant women with various media that can be reached by all pregnant women.

\section{Pendahuluan}

Kehamilan merupakan krisis maturasi yang dapat menimbulkan stres. Namun, jika krisis tersebut dapat ditanggulangi, wanita menjadi siap untuk memasuki fase baru, yaitu mengemban tanggung jawab dan merawat kehamilannya. Konsep diri wanita berubah, siap menjadi orang tua dan menyiapkan peran barunya. Perkembangan ini membutuhkan tugas perkembangan yang pasti dan tuntas, yaitu menerima kehamilan, mengidentifikasi peran sebagai ibu, membangun kembali hubungan dengan suami dan bayi yang dikandungnya serta menyiapkan kelahiran bayinya [1].

Kunjungan antenatal biasanya dimulai segera setelah terlambat haid sehingga dapat diindentifikasi dan dilakukan perawatan terhadap kelainan yang mungkin berkembang pada ibu hamil. Perawatan antenatal didesain untuk memantau pertumbuhan dan perkembangan janin dan menemukan keadaan abnormal untuk mengantisipasi kelahirannya. 
Angka Kematian Ibu (AKI) merupakan salah satu indikator untuk melihat keberhasilan upaya kesehatan ibu.Selain untuk menilai program kesehatan ibu, indikator ini juga mampu menilai derajat kesehatan masyarakat, karena sensitifitasnya terhadap perbaikan pelayanan kesehatan, baik dari sisi aksesibilitas maupun kualitas. Secara umum terjadi penurunan kematian ibu selama periode 1991-2015 dari 390 menjadi 305 per 100.000 kelahiran hidup. Walaupun terjadi kecenderungan penurunan angka kematian ibu, namun tidak berhasil mencapai target MDG's yang harus dicapai yaitusebesar 102 per 100.000 kelahiran hidup pada tahun 2015. Hasil Supas tahun 2015 memperlihatkan angka kematian ibu tiga kali lipat dibandingkan target MDGs.

Upaya percepatan penurunan AKI dapat dilakukan dengan menjamin agar setiap ibu mampu mengakses pelayanan kesehatan ibu yang berkualitas, seperti pelayanan kesehatan ibu hamil, pertolongan persalinan oleh tenaga kesehatan terlatih di fasilitas pelayanan kesehatan, perawatan pasca persalinan bagi ibu dan bayi, perawatan khusus dan rujukan jika terjadi komplikasi, dan pelayanan keluarga berencana termasuk KB pasca persalinan [2].

Perwujudan target penurunan AKI dalam MDGs kedepannya akan dilanjutkan melalui rumusan Sustainable Development Goals (SDG's). Dimana target penurunan AKI secara global adalah 70 kematian per 100,000 kelahiran hidup.Kematian ibu berdampak pada kestabilan ekonomi keluarga. Di dalam keluarga, ibu tidak hanya pengasuh, tapi juga memberikan kontribusi besar pada pengelolaan pendapatan keluarga. Kondisi tersebut berakibat menurunnya kualitas dan peluang kelangsungan hidup bagi bayi yang baru dilahirkan dan anak yang ditinggalkan [3].

Kondisi di atas semakin diperburuk saat Organisasi Kesehatan Dunia, WHO secara resmi mengumumkan wabah virus corona (COVID-19) sebagai pandemi. Pandemi COVID-19 ini melanda hampir seluruh negara di dunia dan berdampak pada berbagai sektor kesehatan maupun nonkesehatan. Ketika akses pelayanan kesehatan terkhusus ibu dan anak terbatas saat merebaknya pandemi COVID-19 seketika itu pulalah terjadi peningkatan angka kehamilan akibat masyarakat terutama pasangan usia subur tidak dapat mengakses program kontrasepsi secara rutin akibat adanya kebijakan pembatasan sosial.

Pertama, kekhawatiran yang akhirnya membuat pasangan mengurungkan diri untuk mendatangi fasilitas kesehatan guna mengikuti program KB. Kedua adanya pembatasan penerimaan pasien dan jam buka di fasilitas kesehatan, klinik, atau bidan terkait aturan physical distancing selama masa pandemi.Akibat fokus perhatian yang luar biasa terhadap COVID-19, seakan-akan pelayanan esensial menjadi terabaikan, padahal sebetulnya ada program-program prioritas yang dilakukan.

Akibat terhambatnya layanan kontrasepsi selama pandemi COVID-19 ini adalah meningkatnya jumlah kehamilan tidak direncanakan. Kondisi ini menyebabkan meningkatnya kuantitas angka kelahiran namun dari segi kualitas justru menurun. BKKBN memprediksi 400.000 kehamilan baru atau tidak direncanakan terjadi selama COVID-19 penurunan ini berdasarkan penurunan $10 \%$ drop outnya pemakaian alat kontrasepsi dari 28 juta keluarga yang kesulitan dalam mengontrol kelahiran [4].

Tidak dipungkiri bahwa kondisi ini akan menimbulkan kecemasan ibu dalam menjalani kehamilannya. Kecemasan dan kekhawatiran pada ibu hamil apabila tidak ditangani secara serius akan membawa dampak dan pengaruh terhadap fisik dan psikis, baik pada ibu maupun janin. Ibu yang mengalami kecemasan atau stres, akan mempengaruhi hipotalamus untuk merangsang kelenjar endokrin yang mengatur kelenjar hipofise. Gangguan akibat kecemasan yang dialami ibu akan menjadi kegawatdaruratan baik bagi ibu sendiri maupun janin dalam proses persalinannya, yang dapat menyebabkan lepasnya hormon stres antara lain Adreno Cortico Tropin Hormone (ACTH), kortisol, katekolamin, ß-Endorphin, Growth Hormone (GH), prolaktin dan Lutenizing Hormone (LH)/Folicle Stimulating Hormone (FSH) [5].

Dukungan sosial merupakan bantuan atau dukungan yang diterima individu dari orang-orang tertentu dalam kehidupannya dan berada dalam lingkungan sosial tertentu dan berada dalam lingkungan sosial tertentu seperti suami, orangtua, mertua, teman atau tetangga yang membuat penerima merasa diperhatikan, dihargai dan dicintai sedangkan untuk orang yang menerima dukungan sosial memahami makna dukungan sosial yang diberikan oleh orang lain. Dukungan sosial sangat dibutuhkan bagi ibu hamil lebih-lebih dalam menjelang masa persalinan tiba. Dukungan sosial yang paling dekat dengan wanita hamil adalah dari pasangannya [6]. 
Dukungan sosial memberikan kenyamanan fisik dan psikologis bagi ibu yang diperoleh dari teman atau keluarga berupa dukungan emosional, penghargaan, instrumental dan informasi. Dukungan sosial memengaruhi kesehatan dengan cara melindungi individu dari efek negatif stres, Selain itu pengaruh positif dari dukungan sosial terutama dari keluarga adalah penyesuaian terhadap kejadian dalam kehidupan yang penuh dengan stres dan kecemasan [7].

Suami adalah salah satu orang yang penting dalam kehidupan seorang ibu. Suami adalah orang yang pertama dan utama dalam memberikan dorongan kepada istrinya sebelum pihak lain turut memberikan dorongan. Pada masa kehamilan kaum suami juga cenderung memberikan reaksi yang positif, serta memberikan dorongan atau dukungan terhadap isterinya [8].

Sejak tanggal 11 Maret 2020 ketika WHO resmi mengumumkan wabah COVID-19 sebagai pandemi global, hampir setiap detik media massa baik media cetak maupun media elektronik di seluruh dunia termasuk Indonesia memberitakan informasi mengenai situasi ini. Disamping pada situasi saat ini semua golongan usia dapat secara mudah mengakses beragam informasi teruatama yang bersal dari media online atau media sosial. Pandemi COVID-19 ini telah menyebabkan adanya perubahan perilaku pengguna media sosial seiring dengan makin intensnya pemberitaan yang membuat masyarakat terus memantau setiap perkembangan terkait COVID-19 melalui berbagai media.

Media terus menyajikan informasi tau pemberitaan mengenai hal-hal kecil, atau informasi yang sebenarnya tak dibutuhkan masyarakat namun bisa berubah menjadi besar, sehingga pemberitaan mengenai COVID-19 ini menjadi momok yang menakutkan bagi semua orang tak terkecuali ibu hamil. Masifnya penyebaran virus ini menimbulkan ketakutan bagi para ibu hamil. Pada dasarnya ibu hamil dalam menjalani masa kehamilannya harus melakukan pemeriksaan rutin, meskipun tidak sesering biasanya, namun hal ini menjadi terkendala karena ketakutan ibu hamil untuk keluar rumah dan bersinggungan dengan orang lain disamping sejumlah rumah sakit, puskesmas, dokter kandungan atau praktik bidan mandiri pun melakukan beberapa penyesuaian terhadap jadwal pemeriksaan kehamilan saat pandemi COVID-19 ini.

Tidak dapat dipungkiri para ibu hamil juga harus mematuhi protokol kesehatan mengenai pemeriksaan kehamilan ini. Walaupun hingga saat ini belum ada hasil penelitian yang membuktikan penularan virus corona dari ibu kepada janin dalam rahim namun secara konsep teori diketahui bahwa saat hamil ibu akan mengalami sejumlah perubahan fisiologis dan imunologis sehingga akan menyebabkan ibu lebih rentan terhadap infeksi terhadap virus ini.

Berdasarkan latar belakang ini maka peneliti tertarik untuk melakukan penelitian mengenai hubungan dukungan sosial dan pemberitaan media terhadap kecemasan ibu menjalani kehamilan masa pandemi COVID-19.

\section{Metode}

Populasi penelitian adalah seluruh ibu hamil di Wilayah Kerja Puskesmas Namorambe Kabupaten Deli Serdang yaitu 998 ibu hamil. Sedangkan sampel merupakan sebagian atau wakil dari populasi yang diteliti. Apabila subyek kurang dari 100, sampel diambil seluruhnya sehingga penelitiannya merupakan penelitian populasi. Selanjutnya jika jumlah subyeknya besar dapat diambil 10\%-15\% atau 20\%-25\% atau lebih. Dengan demikian peneliti menetapkan sampel 10\% dari jumlah populasi. Teknik pengambilan sampel pada penelitian ini dilakukan dengan teknik quota sampling yaitu teknik pengambilan sampel dari populasi yang memenuhi persyaratan ciri-ciri tertentu sampai jatah (kuota) yang telah ditetapkan. Adapun kriteria inklusi responden yang peneliti tetapkan sebagai subjek studi adalah ibu hamil pada usia kehamilan di trimester I, II dan III yang tidak memiliki atau sedang mengalami gangguan jiwa berat, bersedia menjadi responden dan hadir saat penelitian. Hal ini dianggap dapat menggambarkan keadaan populasi sebenarnya (representative).

Data diperoleh secara langsung dari responden dengan teknik wawancara yang berpedoman pada kuesioner yang dibagikan kepada responden yang telah diuji validitas dan reliabilitasnya. Data yang telah dikumpulkan dianalisis dengan uji chi square pada tingkat kepercayaan $95 \%$ $(\alpha=0,05)$ secara univariat dan bivariat dengan sistem komputerisasi. 


\section{Hasil dan Diskusi}

Karakteristik Responden. Mayoritas responden berusia 20-35 tahun yaitu sebanyak 51 orang $(51 \%)$, kehamilan trimester II yaitu sebanyak 54 orang (54\%), mayoritas responden memiliki pendidikan terakhir tingkat menengah yaitu sebanyak 58 orang (58\%) (Tabel 1).

Dukungan Sosial. Mayoritas responden memiliki dukungan sosial yang baik yaitu sebanyak 53 orang $(53 \%)$ (Tabel 1).

Pemberitaan Media. Mayoritas responden mendapat pemberitaan media yang.negatif yaitu sebanyak 55 orang $(55 \%)$ (Tabel 1$)$.

Kecemasan Ibu Menjalani Kehamilan. Mayoritas responden memiliki tingkat kecemasan yang ringan yaitu sebanyak 57 orang (57\%) (Tabel 1).

Tabel 1. Distribusi Frekuensi dan Persentase Karakteristik Responden, Dukungan Sosial, Pemberitaan Media dan Kecemasan Ibu Menjalani Kehamilan Masa Pandemi COVID-19 di Puskesmas Namorambe Kabupaten Deli Serdang

\begin{tabular}{l|c|c}
\hline \multicolumn{1}{c|}{ Variabel } & f & $\%$ \\
\hline Umur & & \\
$<20$ tahun & 27 & 27 \\
$20-35$ tahun & 51 & 51 \\
$>35$ tahun & 22 & 22 \\
\hline Usia Kehamilan & & \\
Trimester I & 25 & 25 \\
Trimester II & 54 & 54 \\
Trimester III & 21 & 21 \\
\hline Pendidikan & & \\
Tinggi & 42 & 42 \\
Menengah & 58 & 58 \\
\hline Dukungan Sosial & & \\
Baik & 53 & 53 \\
Kurang & 47 & 47 \\
\hline Pemberitaan Media & & \\
Positif & 45 & 45 \\
Negatif & 55 & 55 \\
\hline Kecemasan Ibu Menjalani Kehamilan & & \\
Tingkat Ringan & 57 & 57 \\
Tingkat Berat & 43 & \\
\hline
\end{tabular}

Hubungan Dukungan Sosial dengan Kecemasan Ibu Menjalani Kehamilan.

Hasil penelitian tentang hubungan dukungan sosial dengan kecemasan ibu menjalani kehamilan menunjukan bahwaadahubungan dukungan sosial dengan kecemasan ibu menjalani kehamilan ( $p$ value 0,003) dengan OR sebesar 3,187 yang berarti bahwa ibu hamil dengan dukungan sosial yang baik perkiraan peluangnya 3,187 kali mengalami tingkat kecemasan yang ringan dibandingkan dengan ibu hamil dengan dukungan sosial yang kurang (Tabel 2).

Hubungan Pemberitaan Media dengan Kecemasan Ibu Menjalani Kehamilan.

Hasil penelitian tentang hubungan pemberitaan media dengan kecemasan ibu menjalani kehamilan menunjukan bahwaadahubungan pemberitaan media dengan kecemasan ibu menjalani kehamilan ( $p$ value $<0,001)$ dengan OR sebesar 4,56 yang berarti bahwa ibu hamil yang terpapar 
dengan pemberitaan media positif perkiraan peluangnya 4,56 kali mengalami tingkat kecemasan yang ringan dibandingkan dengan ibu hamil dengan pemberitaan media yang negatif (Tabel 3 ).

Tabel 2. Hubungan Dukungan Sosial dengan Kecemasan Ibu Menjalani Kehamilan Masa Pandemi COVID-19 di Puskesmas Namorambe Kabupaten Deli Serdang

\begin{tabular}{|c|c|c|c|c|c|c|c|c|}
\hline \multirow[t]{3}{*}{ Variabel } & \multicolumn{4}{|c|}{$\begin{array}{c}\text { Kecemasan Ibu Menjalani } \\
\text { Kehamilan }\end{array}$} & \multirow{2}{*}{\multicolumn{2}{|c|}{ Total }} & \multirow[t]{3}{*}{ OR } & \multirow[t]{3}{*}{ nilai $p$} \\
\hline & \multicolumn{2}{|c|}{$\begin{array}{c}\text { Kecemasan } \\
\text { Berat }\end{array}$} & \multicolumn{2}{|c|}{$\begin{array}{c}\text { Kecemasan } \\
\text { Ringan }\end{array}$} & & & & \\
\hline & $\mathbf{n}$ & $\%$ & $\mathbf{n}$ & $\%$ & $\mathbf{n}$ & $\%$ & & \\
\hline Dukungan Sosial & & & & & & & & \\
\hline Baik & 15 & 15 & 38 & 38 & 53 & 53 & 3,187 & 0,003 \\
\hline Kurang & 28 & 28 & 19 & 19 & 47 & 47 & & \\
\hline
\end{tabular}

Tabel 3. Hubungan Pemberitaan Media dengan Kecemasan Ibu Menjalani Kehamilan Masa Pandemi COVID-19 di Puskesmas Namorambe Kabupaten Deli Serdang

\begin{tabular}{|c|c|c|c|c|c|c|c|c|}
\hline \multirow[t]{3}{*}{ Variabel } & \multicolumn{4}{|c|}{$\begin{array}{l}\text { Kecemasan Ibu Menjalani } \\
\text { Kehamilan }\end{array}$} & \multirow{2}{*}{\multicolumn{2}{|c|}{ Total }} & \multirow[t]{3}{*}{ OR } & \multirow[t]{3}{*}{ nilai $p$} \\
\hline & \multicolumn{2}{|c|}{$\begin{array}{c}\text { Kecemasan } \\
\text { Berat }\end{array}$} & \multicolumn{2}{|c|}{$\begin{array}{c}\text { Kecemasan } \\
\text { Ringan }\end{array}$} & & & & \\
\hline & $\mathbf{n}$ & $\%$ & $\mathbf{n}$ & $\%$ & $\mathrm{n}$ & $\%$ & & \\
\hline Pemberitaan Media & & & & & & & & \\
\hline Positif & 13 & 13 & 32 & 32 & 45 & 45 & 4,560 & $<0,001$ \\
\hline Negatif & 30 & 30 & 25 & 25 & 55 & 55 & & \\
\hline
\end{tabular}

Berdasarkan hasil penelitian ini diketahui bahwa adahubungan dukungan sosial dengan kecemasan ibu menjalani kehamilan ( $p$ value 0,003 ) dengan OR sebesar 3,187 yang berarti bahwa ibu hamil dengan dukungan sosial yang baik perkiraan peluangnya 3,187 kali mengalami tingkat kecemasan yang ringan dibandingkan dengan ibu hamil dengan dukungan sosial yang kurang.

Hasil penelitian ini sejalan dengan penelitian Melati (2012) dimana terdapat hubungan yang signifikan antara dukungan suami dengan motivasi dalam menjaga kesehatan selama kehamilan. Masa kehamilan merupakan masa kritis maternitas yang dapat menimbulkan stres.Banyak perubahan yang terjadi pada masa ini baik perubahan fisik maupun psikologis, sehingga kondisi fisik yang sehat dan kenyamanan psikologis inilah yang secara tidak langsung menimbulkan pergerakan positif dalam diri ibu hamil sehingga ibu termotivasi untuk menjaga kesehatannya selama kehamilan [8].

Penelitian lain yang mendukung penelitian ini dilakukan oleh Sari, et.al (2020) dimana dukungan keluarga terutama suami sangat dominan dalam mengurangi kecemasan selama kehamilan. Tempat inilah ibu menyampaikan keluh kesah yang dirasakan selama hamil, keluh kesah ini jika ditanggapi dengan positif, memberikan dukungan moral, motivasi sehingga beban moral yang dirasakan akan berkurang karena peranan suami, sehingga ibu merasa nyaman selama hamil dan mau melakukan apa yang baik untuk kehamilannya [8].

Dukungan digambarkan sebagai proses interaktif yang dipengaruhi oleh usia, pengalaman, kepribadian dan lingkungan. Dukungan yang dimaksud ini meliputi dukungan emosional yang melibatkan pemberian empati, cinta dan kepercayaan serta menjadikan ibu merasa aman.Dukungan emosional salah satu faktor yang berperan dalam membangun pengalaman yang positif sehingga ibu dapat menahan efek negatif dari stres dan mengelola perasaan cemas selama kehamilan.

Mayoritas ibu akan mendapatkan dukungan emosional dari pasangannya. Ketika pasangan terlibat dalam setiap proses yang dijalani ibu selama melewati masa kehamilannya maka hal ini dapat menjadi penguatan dan persiapan psikologi ibu yang lebih baik sampai dengan proses persalinan [9].

Secara tidak langsung pandemik COVID-19 yang tak kunjung usai tentu saja menimbulkan kekhawatiran, bagi semua orang tak terkecuali ibu hamil.Apalagi hingga saat ini belum ditemukannya obat definitif atau vaksin yang dapat menjadi pegangan semua orang untuk 
menghadapi infeksi jenis virus ini.Berdasarkan informasi dari WHO (2020) hingga saat ini masih dilakukanpenelitian untuk memahami dampak infeksi COVID-19 pada ibu hamil. Data yang tersedia masih terbatas, namun saat ini masih belum ada bukti yang menyatakan bahwa ibu hamil lebih berisiko terkena penyakit parah dibandingkan populasi umum.

Namun, karena adanya perubahan pada tubuh dan sistem imunitas ibu hamil, mereka dapat mengalami dampak yang cukup parah karena beberapa penyakit infeksi saluran pernapasan. Tentu hal ini menimbulkan reaksi stres bagi ibu hamil, stres membuat ibu merasa keselamatan ia dan dirinya menjadi terancam. Belum diketahui apakah seorang ibu hamil yang terjangkit COVID-19 dapat menularkan virus tersebut ke janin atau bayi selama kehamilan atau persalinan. Sampai saat ini, virus ini belum ditemukan di dalam sampel cairan amniotik/ketuban atau ASI.Namun meskipun demikian tentu saja hal ini menimbulkan reaksi stres dalam diri ibu hamil.Stres merupakan reaksi tubuh yang muncul pada seseorang kerena merasa terancam, tertekan atau karena adanya perubahan.

Berdasarkan penelitian diketahui mayoritas ibu khawatir terhadap kondisi janin yang dikandungnya karena ibu tidak bisa melakukan pemeriksaan seperti biasanya ke fasilitas tenaga kesehatan ya. Sehingga dengan terjadinya perubahan situasi ini membuat ibu hamil selalu dalam kondisi "fight" atau siaga terus menerus, dimana ketika ibu stres ibu akan mengalami gejala psikomatik yang muncul akibat ketidakstabilan sistem saraf otonom yang muncul sebagai reaksi kesiapsiagaan ibu ketika menghadapi ancaman termasuk ancaman terhadap kesehatan diri dan bayi yang dikandungnya. Hal ini didukung dari hasil penelitian dimana mayoritas ibu selalu mengupdate informasi mengenai jumlah kasus kematian akibat infeksi virus COVID-19 baik pada media cetak maupun media elektronik sehingga membuat dirinya semakin khawatir dalam 30 hari terakhir dan ibu selalu mencari tau sendiri cara merawat kehamilannya selama berada di rumah saja dalam 30 hari terakhir. Hal ini dilakukan ibu hamil karena selama pandemi layanan kesehatan ibu dan anak juga semakin terbatas termasuk untuk pemeriksaan ibu hamil meski pemerintah sudah mencanangkan era kebiasaan baru namun ibu tetap diberdayakan untuk lebih memperhatikan kesehatannya dan tanggap terhadap setiap perubahan yang terjadi di setiap tahap kehamilannya.

Ibu hamil juga jangan enggan untuk menuju fasilitas tenaga kesehatan apabila memiliki keluhan terkait dengan kehamilannya asalkan mematuhi protokol kesehatan yang berlaku, masa adaptasi kebiasaan baru merupakan masa transisi dimana kehidupan baru akan dimulai untuk membangun produktivitas dan optimism masyarakat dengan tentunya harus bergandengan dengan komitmen untuk memenuhi seluruh tindakan pencegahan terhadap penularan COVID-19 yang telah digaungkan oleh pemerintah.

Berdasarkan hasil penelitian tentang hubungan pemberitaan media dengan kecemasan ibu menjalani kehamilan menunjukan bahwaadahubungan pemberitaan media dengan kecemasan ibu menjalani kehamilan ( $p$ value $<0,001)$ dengan OR sebesar 4,56 yang berarti bahwa ibu hamil yang terpapar dengan pemberitaan media positif perkiraan peluangnya 4,56 kali mengalami tingkat kecemasan yang ringan dibandingkan dengan ibu hamil dengan pemberitaan media yang negatif.

Dukungan lain yang tak kalah pentingnya ialah dukungan informatif dimana orang-orang di sekitar ibu hamil menawarkan informasi yang positif sehingga dapat memberikan dampak yang positif serta mengurangi perasaan kecemasan. Berdasarkan Andriani (2019) diketahui bahwa ibu hamil harus memiliki dukungan pengetahuan dan informasi yang cukup baginya untuk meneguhkan sikap dan menjadi sebuah perilaku kesehatan yang diinginkan.

Sikap dan kepatuhan yang terjadi pada seseorang dipengaruhi salah satunya oleh informasi yang diterima seseorang. Pada dasarnya selama kehamilan ibu akan menerima banyak informasi terkait dengan perawatan kehamilan dari tenaga kesehatan salah satunya saat melakukan antenatal care. Pemantauan kehamilan selama antenatal care sangat menentukan keberhasilan bagi kesehatan ibu hamiluntuk memantau berbagai kemungkinan gangguan patologis atau risiko tinggi yang bisa terjadi sehingga dapat diketahui secara dini dan mengambil langkah-langkah yang intensif.Namun terbatasnya layanan kesehatan selama pandemi COVID-19 turut memengaruhi layanan kesehatan ibu dan anak.

Perkembangan ilmu pengetahuan dan teknologi saat ini membuat semua orang dapat dengan mudah mengakses berbagai informasi dari media apapun baik elektronik maupun non elektronik. Sejak WHO menetapkan wabah COVID-19 sebagai pandemik gobal perhatian publik dan pemberitaan media seolah hanya tertuju kesana. Mulai terjadi perubahan yang signifikan terhadap 
pola konsumsi media, masyarakat semakin intens memantau setiap perkembangan terkait COVID19.

Berdasarkan hasil penelitian diketahui bahwa mayoritas ibu mendapat informasi bahwa jumlah korban terinfeksi virus COVID-19 semakin meningkat dari waktu ke waktu secara drastis terutama jumlah kasus yang berada di daerah dimana ibu tinggal yaitu sebanyak 53 responden (53\%) dan ibu mendapat informasi bahwa kehamilan dapat meningkatkan risiko penularan COVID-19 dibandingkan dengan yang tidak hamil yaitu sebanyak 51 responden $(51 \%)$. Informasi mengenai hal-hal kecil yang dianggap tak penting berubah menjadi besar, sehingga pemberitaan mengenai COVID-19 kian menjadi momok yang menakutkan.

Kecemasan yang terjadi pada ibu hamil berdasarkan penelitian ini adalah kondisi pandemi COVID-19 membuat ibu menunda melakukan pemeriksaan kehamilan karena ia tidak mau bersinggungan dengan RS atau Puskesmas dalam 30 hari terakhir dan ibu selalu menceritakan kekhawatiran kondisi pandemi COVID-19 yang tidak kunjung selesai ini kepada suami atau keluarga lainnya dalam 30 hari terakhir.

Disamping itu pula ibu memperoleh informasi postif lewat pemberitaan media yang membuat ibu lebih waspada dimana berdasarkan hasil penelitian ibu hamil mendapat informasi mengenai cara mengurangi risiko penularan infeksi COVID-19 dengan menggunakan masker, menjaga kebersihan tangan dengan hand sanitizer berbasis alkohol atau dengan mencuci tangan dengan sabun dan air mengalir saat melakukan aktivitasdi luar rumah.

\section{Kesimpulan}

Dapat disimpulkan bahwa dukungan sosial dan pemberitaan media terbukti berhubungan dengan kecemasan ibumenjalani kehamilan masa pandemi COVID-19.Disarankan bagi tenaga kesehatan agar dapat beradaptasi dengan pelayanan kesehatan yang disesuaikan dengan protokol kesehatan yang berfokus pada upaya promosi kesehatan, pencegahan penyakit serta pemberdayaan ibu hamil. Meskipun kunjungan fasilitas kesehatan hanya diprioritaskan pada ibu hamil yang mengalami gangguan namun tenaga kesehatan tetap dituntut untuk dapat berinovasi mengembangkan edukasi kepada ibu hamil dengan berbagai media yang dapat dijangkau oleh semua ibu hamil. Edukasi yang dimaksud dapat dilakukan dengan meminta ibu hamil menunda kontrol ke puskesmas jika tidak ada tanda bahaya kehamilan.Konsultasi kehamilan dilakukan melalui sistem layanan kesehatan jarak jauh (telemedicine) dengan bidan asuh yang memanfaatkan Whatsapp Group misalnya ibu hamil hamil didorong untuk mempelajari buku Kesehatan Ibu dan Anak.Media sosial ini dapat dimanfaatkan ibu hamil untuk berkonsultasi tentang kehamilannya secara virtual tanpa harus pergi ke fasilitas layanan kesehatan.

\section{Ucapan Terima Kasih}

Ucapan terima kasih peneliti sampaikan kepada responden yang telah bekerjasama dengan penelIti dengan baik serta Kepala Puskesmas Namorambe yang telah mengijinkan dilakukannya kegiatan penelitian dan Ketua STIKes Murni Teguh yang telah memberikan motivasi dan dorongan pada dosen dalam melakukan kegiatan tri dharma perguruan tinggi.

\section{Referensi}

[1] Susanti, N.N. Psikologi Kehamilan. Jakarta: EGC. Diakses tanggal 05 Agustus 2020. URL:https://books.google.co.id/books?id=AYbr7czGm9EC\&pg=PA17\&dq=psikologi+ibu+ hamil\&hl=id\&sa=X\&ved=2ahUKEwi38su4y YPrAhWFXSsKHX1JAeYQ6AEwAHoECAQ QAg\#v=onepage\&q=psikologi\%20ibu\%20hamil\&f=false. 2012.

[2] Kementerian Kesehatan R.I. Profil Kesehatan Indonesia Tahun 2018. Jakarta. Diakses tanggal 05 Agustus 2020. URL: https://www.google.com/url?sa=t\&rct=j\&q= $\&$ esrc $=$ s\&source $=$ web $\& c d=\& c a d=r j a \& u a c t=8 \& v e d=2$ ahUKEwistL 6 KzoPrAhXEZCsKHbgL DjEQFjAFegQIBBAB\&url=http\%3A\%2F\%2Fwww.kemkes.go.id\%2Fresources\%2Fdownlo ad\%2Fpusdatin \%2Fprofil-kesehatan-indonesia\%2Fprofil-kesehatan-indonesia-2018.pdf\&usg =AOvVaw3pR2q0LBhKDSGfoEzyDYM7. 2019. 
[3] Kementerian Pemberdayaan Perempuan dan Perlindungan Anak. Press Release "Diperlukan Komitmen dan Peran Serta Masyarakat untuk Menekan Angka Kematian Ibu (AKI). Diakses tanggal 05 Agustus 2020. URL: https://www.kemenpppa.go.id/index.php/ page/read/29/122/press-release-menteri-pp-dan-pa-diperlukan-komitmen-dan-peran-sertamasyarakat-untuk-menekan-angka-kematian-ibu-aki. 2015.

[4] Saputro, I. BKKBN Prediksi Angka Kehamilan Baru di Indonesia Capai 420 Ribu di Masa Pandemi Covid-19. Artikel Tribun Palu. Diakses tanggal 05 Agustus 2020. URL: https://palu.tribunnews.com/2020/07/15/bkkbn-prediksi-angka-kehamilan-baru-di-indonesiacapai-420-ribu-di-masa-pandemi-covid-19. 2020.

[5] Mukhadiono, Subagyo, W., Wahyuningsih, DHubungan antara Dukungan Suami dengan Tingkat Kecemasan pada Ibu Primigravida Trimester III dalam Menghadapi Persalinan. Jurnal Keperawatan Soedirman 10(10): 53-59. Diakses tanggal 05 Agustus 2020. URL: https://www.google.com/url?sa=t\&rct=j\&q=\&esrc=s\&source=web\&cd=\&cad=rja\&uact $=8 \&$ ved=2ahUKEwjy4f2I5oPrAhVCaCsKHYELA5oQFjAAegQIBxAB\&url=http\%3A\%2F\%2Fj ks.fikes.unsoed.ac.id\%2Findex.php\%2Fjks\%2Farticle\%2Fview\%2F592\&usg=AOvVaw0A9 GXhwN5OL8L91YXjONOr. 2015.

[6] Maharani, T.I \& Fakhrurrozi, M. Hubungan Dukungan Sosial dan Kecemasan dalam Menghadapi Persalinan pada Ibu Hamil Trimester III. Fakultas Psikologi Universitas Gunadarma. Jurnal Ilmiah Psikologi 2(7): 61-67. Diakses tanggal 10 Agustus 2020. URL: $\mathrm{https}: / / \mathrm{www} \cdot$ google.com/url? sa $=\mathrm{t} \& \mathrm{rct}=\mathrm{j} \& \mathrm{q}=\&$ esrc $=\mathrm{s} \&$ source $=\mathrm{web} \& \mathrm{~cd}=\& \mathrm{cad}=\mathrm{rja} \&$ uact $=8 \&$ ved=2ahUKEwiKmPz9yo_rAhWBbn0KHfjBDt8QFjABegQIARAB\&url=https\%3A\%2F\%2 Fejournal.gunadarma.ac.id\%2Findex.php\%2Fpsiko\%2Farticle\%2Fview\%2F1131\%2F991\&u sg=AOvVaw3wD-m8URSYNAMES7RNnJql. 2014.

[7] Ningsih, I.O. Hubungan anatara Dukungan Sosial terhadap Tingkat Kecemasan pada Ibu Hamil di Pontianak Barat. Fakultas Kedokteran Universitas Tanjung Pura Pontianak Barat. Naskah Publikasi. Diakses tanggal 10 Agustus 2020. URL: https://www.neliti.com/id/ publications/193353/hubungan-antara-dukungan-sosial-terhadap-tingkat-kecemasan-padaibu-hamil-di-pon. 2016.

[8] Melati, R \& Raudatussalamah. Hubungan Dukungan Sosial Suami dengan Motivasi dalam Menjaga Kesehatan selama Kehamilan. Jurnal Psikologi 8(2): 111-118. Diakes tanggal 03 September 2020. URL: http://ejournal.uin-suska.ac.id/index.php/psikologi/article/ view/194. 2012.

[9] Backstrom, C. Professional and Social Support for First-time Mothers and Partners During Childbearing. Doctoral Thesis in Health and care Sciences. Jonkoping: School of Health and Welfare. Diakses tanggal 03 September 2020. URL: https://www.divaportal.org/smash/get/diva2:1170624/FULLTEXT01.pdf. 2018.

[10] World Health Organization. Pertanyaan dan Jawaban Terkait COVID-19 untuk Masa Kehamilan, Persalinan, dan Menyusui. Artikel Online.Diakses tanggal 07 September 2020. URL: https://www.who.int/indonesia/news/novel-coronavirus/qa-during-pregnancy

[11] Andriani, R. 2019. Pencegahan Kematian Ibu saat Hamil dan Melahirkan Berbasis Komunitas. Yogyakarta: CV Budi Utama. 2020.

[12] Sari, I.P., Suroyo, R.B, Fitria, A. Analisis Faktor Determinan Perilaku Ibu dalam Kehamilan terhadap Berat Badan Bayi di Rumah Sakit Umum Daerah Simeulue.Journal of Issues in Midewifery 3(3): 97-119. Diakses tanggal 07 September 2020. URL: https://joim.ub.ac.id/index.php/joim/article/download/265/60. 2020.

[13] Triyaningsih, H. Efek Pemberitaan Media Massa terhadap Persepsi Masyarakat Pamekasan tentang Virus Corona. Meyarsa 1(1). Diakses tanggal 28 Oktober 2020.https://www.google.com/url?sa=t\&rct=j\&q=\&esrc=s\&source=web\&cd=\&cad=rja\&uac $\mathrm{t}=8 \&$ ved $=2$ ahUKEwiw34a6h9bsAhXZbCsKHU2JBA8QFjADegQIBBAC\&url=http $\% 3 \mathrm{~A} \% 2$ F\%2Fejournal.iainmadura.ac.id\%2Findex.php\%2Fmeyarsa\%2Farticle\%2Fdownload\%2F322 2\%2F1831\&usg=AOvVaw2vGEIiS51DMhtKLY1cQ0L3. 2020. 